Didaché: Journal of Christian Education

Vol. 1, No. 2 (2020): 153-168

journal.sttsimpson.ac.id/index.php/DJCE

e-ISSN: 2722-8584

\title{
Keluarga Harmonis berdasarkan Kolose 3:18-21 dan Pengaruhnya terhadap Etika Pergaulan Anak
}

\author{
Eka Preskila, *Bakhoh Jatmiko \\ Sekolah Tinggi Theologia Nazarene Indonesia \\ *Email: djatcair@gmail.com
}

\begin{abstract}
The various problems related to children character and behavior are emerging in manydiscourses. Bullying, group fighting, moral violance, and crime are often involved children whether as the performers or victims. This phenomenon can not be separated to the existance of the family as the very first "school" for the childen. This research is conducted to see the corelation between the family congruity according to Colossians 3:18-24 and children's social intercourse ethics. This research involved fith grade 50 students of Christian Elementary School of Kalam Kudus in Yogyakarta as the sample. The research found that there is a strong correlation between the family harmony and student's social intercourse ethics. The parent's example in managing relation between the family membersis a strong factor in shaping children's social intercourse ethics, due to the fact that the children are good imitator.
\end{abstract}

Keywords: Harmony Family, Social Ethics, Character Building, Children

\begin{abstract}
Abstrak
Berbagai persoalan berkaitan dengan karakter dan perilaku anak-anak kian mengemuka di berbagai diskusi. Perundungan, tawuran, pelanggaran moral, dan kriminal sering melibatkan anak-anak baik sebagai pelaku maupun korban. Berbagai fenomena tersebut tidak dapat dipisahkan dari keberadaan keluarga sebagai "sekolah" pertama bagi anak. Penelitian ini dilakukan dengan tujuan untuk melihat korelasi keharmonisan keluarga berdasarkan Kolose 3:18-24 dengan etika pergaulan anak. Riset melibatkan 50 orang siswa kelas V di SD Kristen Kalam Kudus Yogyakarta sebagai sampel. Simpulan dari penelitian yang dilakukan adalah ada hubungan yang kuat antara keharmonisan keluarga terhadap etika pergaulan siswa. Keteladanan orang tua dalam mengembangkan hubungan antar keluarga merupakan faktoryang kuat dalam membentuk etika pergaulan anak di lingkungan sosialnya, sebab anak pada hakekatnya adalah peniru yang baik.
\end{abstract}

Kata Kunci: Keharmonisan Keluarga, Etika Pergaulan, Pengembangan Karakter, Anak 


\section{Pendahuluan}

Keluarga adalah sekolah karakter mula-mula bagi seorang anak. Nuansa hubungan setiap anggota keluarga akan membawa pengaruh signifikan di dalam pembangunan dan pembentukan nilai diri serta karakter anak termasuk etika pergaulannya. Pendidikan karakter dilihat sebagai hal penting dalam membangun sebuah tatanan sosial dalam kehidupan bermasyarakat, berbangsa dan bernegara (Wulandari, 2012). Urgensi kajian di dalam bidang ini semakin meningkat seiring denganfenomena dekadensi moral dan etika di dalam kehidupan sehari-hari. Persoalan sosial dalam kehidupan sehari-hari seperti KKN (Korupsi, Kolusi dan Nepotisme), pembunuhan, perceraian, perselingkuhan, penindasan, pencurian, tawuran dan lain sebagainya merupakan persoalan yang berakar pada krisis moral dan karakter yang tidak lepas dari penguatan pendidikan karakter dalam keluarga. Sebagai contoh, di Indonesia berdasarkan Indeks Persepsi Korupsi pada tahun 2010 meningkat dari 2,6\% menjadi 2,8\% di tahun 2019. Dengan skor tersebut, Indonesia menjadi negara paling korup pertama dari 12 negara Asia dan berada diurutan ketiga dari 180 negara di dunia, berdasarkan hasil penelitian dari political and economic rich consultacy di Hongkong dan transparancy global index di Jerman (Syarbini, 2014).

Di bidang lingkungan sekolah pelanggaran etika juga dilaporkan mengalami peningkatan. Menurut data KPAI (Komisi Perlindungan Anak Indonesia) pada tahun 2019, terjadi peningkatan kasus bullying yang berupa kekerasan fisik, psikis dan seksual yang terjadi dijenjang sekolah dasar yaitu mencapai 25 kasus atau 67\% dari keseluruhan kasus yang ada. Hal tersebut membuktikan ada permasalahan serius yang berhubungan dengan karakter (Syarbini, 2014). Urgensi persoalan ini direspon oleh Sekolah Dasar Kristen Kalam Kudus Yogyakarta, yang menjadi obyek penelitian ini yang mengembangkan pendidikan karakter yang mencakup etika pergaulan. Perundungan, tawuran pelajar (klithih), kriminalitas, dan berbagai hal lain yang berkaitan dengan pelanggaran etika perlu dipikirkan secara serius. SD Kristen Kalam Kudus, memiliki program Buddy, yang merupakan langkah prefentif praktik bullying di lingkungan sekolah. Setiap siswa bertanggung jawab sebagai Buddy - teman, yang harus melaporkan setiap tindakan perundungan ke pihak sekolah. Selain itu juga ada budaya SMART, S (Senyum, Salam, Sapa, Sopan), M (Maaf), A (Antri), R (Ringkas, Rapi, Resik, Rawat, Rajin), T (Terimakasih) (Handsbook Code Of Conduct Tahun Pelajaran 2019/2020, 2019). 
Di ranah psikologi pendidikan, pembangunan karakter diyakini tidak hanya terjadi di seting formal saja. Salah satu cabang konsep pembangunan karakter yang cukup populer adalah Outdoor Adventure Education (OAE). Pendidik seperti Ewert dan Prouty menyatakan bahwa pola kerja OAE sebagai program character building dengan melibatkan peserta untuk masuk pada pengalaman "character-trait" yang ada di sekitarnya (Ewert \& Sibthorp, 2014; Prouty, Panicucci, \& Collinson, 2007). Meskipun konsep ini juga mendapat kritik oleh para peneliti yang lain. Misalnya, Brookes melihat bahwa OAE mengabaikan keunikan setiap individu, oleh karenanya, "character-trait" yang diterapkan seharusnya berubah menjadi "personal trait development"(Brookes, 2003). Kajian tentang pendidikan karakter juga berkembang dalam perjumpaannya dengan bidang sosial dan dan keagamaan (Sebagai kajian pembanding lihat Jahroh \& Sutarna, 2016; Purnamasari, 2017). Pemikiran ini mengarahkan pada konsep pengembangan potensi anak bukan hanya di dalam ranah kognitifnya saja, tetapi juga di dalam aspek afektifnya dan psikomotorik berdasarkan nilai-nilai keagamaan. Di dalam hal ini, keluarga sebagai entitas sosial terkecil memiliki peran penting dalam pendidikan karakter sesuai dengan nilainilai spiritual bagi anggota-anggota di dalamnya, khususnya bagi seorang anak. Hutcheon melihat keluarga sebagai tempat anak mendapat "first-hand basis values" yang membentuk pola interaksi anak dengan teman-temannya termasuk dalam nilai etika pergaulannya (Hutcheon, 1999, pp. 129-134).

Hal ini selaras dengan konsep keluarga di dalam Kekristenan. Keluarga dipandang lebih dari sekedar sebagai ikatan sosial, namun hakikat keluarga juga berkaitan dengan kebenaran teologis yang terkait dengan keberadaan Sang Pencipta, pola hubungan dengan umat serta tujuan-Nya bagi manusia (Jatmiko, 2019, pp. 83-103). Oleh karena itu, peran dan fungsi keluarga memiliki posisi yang penting dalam iman Kristen. Keluarga adalah "sekolah" bagi anak untuk mendapatkan pendidikan karakter dan nilai-nilai Alkitabiah yang harus dipegang. Alkitab memberikan standar khusus bagi pola hubungan setiap anggota keluarga, sehingga keluarga menjadi "lingkungan" ideal bagi tumbuh kembang karakter anak. Paulus menulis dalam Kolose 3 tentang hubungan antar anggota rumah tangga yang berguna untuk menjaga keharmonisan di dalam keluarga yang berpengaruh bagi etika pergaulan anak-anak.

Secara umum dalam Kolose 3:18-21 terdapat 3 unsur, yakni pertama, peran manusia yakni suami, isteri dan anak, kedua, perintah yakni tunduklah, taatilah dan lain sebagainya, ketiga, motivasi perintah, yakni karena Tuhan 
(Barus, 2018). Melalui penggalian teks, ditemukan prinsip-prinsip dalam membangun keluarga yang harmonis menurut Kolose 3:18-21 adalah: pertama, takut akan Tuhan, kedua, kasih, ketiga, ketaatan, keempat, keteladanan, kelima, komunikasi, keenam, kepedulian. Prinsip-prinsip tersebut dijadikan sebagai komponen variabel $X$ di dalam penelitian ini. Ayat 18 dalam Terjemahan Baru berbunyi: "Hai isteri-isteri, tunduklah pada suamimu, sebagaimana demikian seharusnya di dalam Tuhan." Kata tunduklah dalam bahasa Yunani

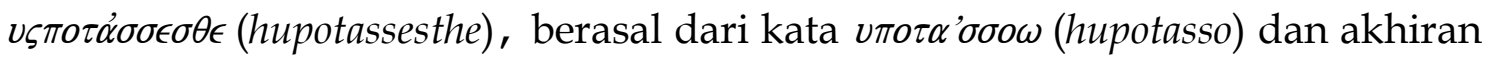
kata $\epsilon \sigma \theta \epsilon$ (este) yang merupakan akhiran kata kerja untuk orang kedua, jamak, pasif, menengah/medial yang berarti subyek melakukan tindakan untuk diri sendiri, pada hal ini yaitu para isteri, dan merupakan kata imperatif atau merupakan perintah. Hupotasso dalam bahasa inggris submit, (New English Translation, Alkitab Android, n.d.) memiliki arti menyerahkan, memasrahkan, menundukkan atau tunduk, yaitu menundukkan dirinya sendiri (para isteri) yang digunakan sebanyak 23 kali oleh Paulus dan 38 kali dalam Perjanjian Baru.

Dalam Perjanjian Baru kata hupotasso ditulis sebanyak 38 kali, yang memiliki beberapa arti yaitu takhluk, seperti dalam Lukas 10:17; 10:20; Roma 8:7,20; Roma 13:1;5, I Korintus 16:16; Filipi 3:21, Ibrani 2:5,8; I Petrus 3:22. Arti lain yakni tunduk (upotassetai) yang juga memiliki akar kata hupotasso, yang ada dalam Efesus 5:24; Kolose 3:18; I Petrus 2:13, 18; I Petrus 3:5,15; I Petrus 5:5. Arti lainnya yakni taat (upotassomenas) yang juga memiliki akar kata hupotasso yakni terdapat dalam Titus 2:5; Titus 2:9; Titus 3:1; Ibrani 12:9. Jadi kata hupotasso dapat diartikan sebagai takhluk, taat atau tunduk. Namun dalam konteks keluarga, ayat yang selaras dengan Kolose 3:18 adalah Efesus 5:24 tentang ketundukan isteri kepada suami. Perintah ini diberikan Paulus untuk perempuan yang sudah menikah yaitu isteri. Kata tunduk berarti penaklukan diri secara sukarela, para isteri di nasehati agar menakhlukan diri atau menundukkan diri secara sukarela kepada suami, kemudian Paulus menjelaskan alasannya, karena demikian seharusnya dalam Tuhan. Hal ini bukan berarti perempuan memiliki martabat yang lebih rendah daripada lakilaki. Namun, Paulus menunjuk pada suatu tatanan hierarki ilahi, yaitu peran isteri dibawah suami, suami adalah kepala (Ef 5:23,24) sama seperti Kristus yang adalah kepala jemaat. Isteri tunduk kepada suami bukan karena aturan yang berlaku dalam masyarakat atau karena lelaki lebih kuat, namun hal itu dilakukan karena Kristus. Isteri tunduk kepada suami karena keduanya telah terikat menjadi satu dalam persekutuan di dalam Kristus, oleh karena itu harus 
mengikuti pola atau tatanan hukum Kristus. Sehingga dari ayat ini penulis mengambil prinsip tunduk/taat dan takut akan Tuhan.

Ayat 19 mengatakan: "hai suami-suami, kasihilah isterimu dan

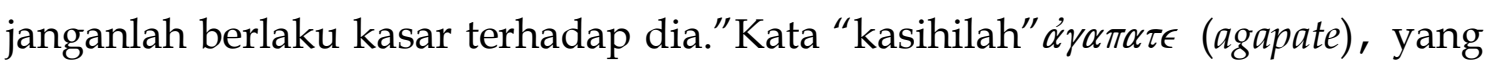
berasal dari akar kata $\alpha \gamma \alpha \pi \alpha \omega$ (agapao) merupakan kata kerja, orang kedua, jamak, kini, aktif, imperatif (perintah). Dalam bahasa inggris love, to love (in social or moral sense), to welcome, to entertain, to be fond of, to love dearly, yang berarti mengasihi, menunjukkan kasih, menyukai, merupakan kata kerja dan muncul sebanyak 143 kali dalam Perjanjian Baru, seperti dalam Matius 5:11; Lukas 6:32,35; Yohanes 13:34; Yohanes 14:15; Yohanes 15:12; Yohanes 15:17; Efesus 5:25; I Petrus 1:8; I Petrus 2:17. Kata kasihilah menunjukkan perintah yang harus dilakukan suami kepada isteri yang merupakan kata kerja, berarti kasih disini tidak bersifat emosi atau perasaan saja, namun lebih kepada tindakan kasih, yaitu mengasihi. Hal ini merupakan timbal balik dari ayat sebelumnya dimana isteri diminta untuk menyerahkan, memasrahkan dirinya untuk suami, begitu pula suami memiliki kewajiban untuk mengasihi isteri. Menurut Lohse pada jaman itu kasih tidak dikenal dalam masyarakat Yunani, suami sebagai kepala keluarga hanya menggunakan kuasanya untuk memimpin setiap anggota keluarga (Eduard, Lohse, 2018). Pada masa perjanjian Lama, yaitu orang Israel pada jaman Alkitab, memiliki bentuk kehidupan keluarga yang patriarkhal (berpusat pada ayah), seorang perempuan harus mematuhi ayahnya atau suami jika sudah menikah. Nilai seorang perempuan hanya separuh dari nilai seorang laki-laki (Im. 27:1-8). Suami yang dalam sebagian bahasa Ibrani memiliki arti menguasai, memerintah. Sebagai kepala keluarga, suami bertanggung jawab atas kesejahteraan keluarganya. Seorang ayah dalam budaya oang Israel menerima kedudukan sebagai pemimpin rohani atau imam dalam keluarga (Kej. 12:3,8; Ayb. 1:5) (Packer, Tenney, \& White Jr., 2014).

Wajar apabila budaya tersebut masih ada dalam masyarakat Yahudi, dimana dalam keluarga, suami adalah seorang pemimpin, yang menguasai, dan memerintah, dan isteri ada dibawah suami (tatanan hierarki). Jadi perintah yang diberikan Paulus kepada keluarga di Kolose ini merupakan perintah baru, yaitu mengasihi isteri, mengasihi sebagai penolong, bukan sesorang yang dikuasai, yang diperintah dan yang nilainya rebih rendah. Perintah baru ini juga dikatakan Yesus dalam Yohanes 13:34, dimana Yesus memberikan perintah baru untuk para murid yakni untuk saling mengasihi. 
Kata kasihilah atau agapate adalah kata aoris, aktif, imperatif (Anouw, 2016). Komposisi gramatikal kala aoris, diatesis aktif dan modus imperatif merupakan hal yang menarik untuk diamati. Boyer dalam penelitiannya, menemukan bahwa 47\% modus imperatif yang digunakan di dalam Perjanjian Baru berpasangan dengan kala aoris (Boyer, 1987, pp. 35-54). Penggunaan imperatif pada tensis yang berbeda akan memberikan nuansa yang berbeda pula pada jenis tindakan (kind of action) yang ingin disampaikan oleh penulis (Robertson, 1934, pp. 832-854). Ketika modus imperatif digunakan pada kata kerja kini, hal ini menunjukkan perintah atau permohonan yang meminta tindakan atau pengulangan tindakan yang lebih umum, universal, menjadi kebiasaan, atau tindakan yang merupakan karakter dari pelaku; sedangkan aoris imperatif digunakan untuk menyatakan perintah atau permohonan yang spesifik, tertentu dan berkaitan pada tindakan sehari-hari (praktis) (Boyer, 1987, p. 41). Dengan demikian, ayat 25 dapat dimengerti bahwa kasih Kristus terhadap gereja-Nya harus menjadi pedoman dalam hubungan suami dan istri. Paulus menginstruksikan supaya kasih tercermin di dalam kehidupan sehari-hari.

Selain mengasihi pada ayat ini Paulus juga menasehati para suami agar tidak menyakiti hati istri, yang dalam bahasa Yunani dalam ayat ini menggunakan kata $\mu \dot{\eta} \pi \iota \kappa \rho \alpha i \nu \epsilon \sigma \theta$ (pikrainesthe) yang merupakan kata kerja, orang kedua, jamak, kini, pasif, imperatif (perintah), berasal dari kata $\pi \iota \kappa \rho \alpha i \nu \omega$ (pikraino), muncul sebanyak 4 kali, yang bermakna menjadikan pahit, bersikap membenci, berlaku kasar, dengan adanya partikel ingkar $\mu \dot{\eta}$ yang merupakan kata keterangan tidak, jangan (jangan), juga sebagai interogatif yang menyiratkan jawaban negatif, maka arti kata dalam ayat ini menjadi tidak menjadikan pahit atau janganlah menjadikan pahit. Dalam ayat ini Paulus memberi nasehat kepada suami agar tidak menyakiti hati isteri atau membuat kepahitan di hati isteri. Jadi dalam ayat 19 ini Paulus memberikan perintah kepada para suami untuk terus mengasihi isteri dan melarang suami untuk menyakiti isteri dengan tidak berlaku kasar terhadap dia, sehingga pada ayat ini penulis mengambil prinsip kasih, yaitu kasih sebagai sebuah tindakan yang harus dilakukan terus menerus.

Ayat 20 berbunyi: "hai anak-anak, taatilah orang tuamu dalam segala hal, karena itulah yang indah di dalam Tuhan." Kata taat berasal dari bahasa

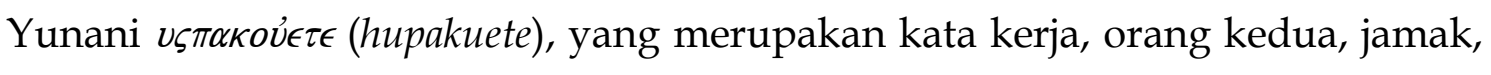
kini, aktif, imperatif (perintah), dalam bahasa inggris King James Version, obey,

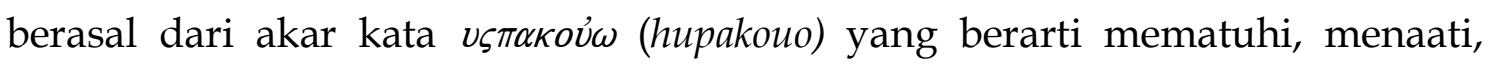


mengikuti, mendengar (yaitu membuka pintu), merupakan kata kerja yang muncul sebanyak 21 kali dalam Perjanjian Baru. Pada masa itu hukum Romawi mengharuskan anak untuk taat kepada bapanya yang disebut patria potestas, hal tersebut menggambarkan tentang kekuasaan seorang ayah terhadap anak bahwa ketaatan yang harus dimiliki seorang anak kepada ayahnya adalah ketaatan seperti budak (William Barclay, 2005) Legalitas dalam patria potestas memberi hak penuh untuk memiliki kekuasaan atas kehidupan seorang anak termasuk mengatur pernikahan, memaksakan perceraian, menterlantarkan, menjual atau bahkan membunuh anak-anak mereka (Shelton, 1998).

Ketaatan anak kepada orang tua mencakup dalam segala hal, namun kata selanjutnya yang dipakai Paulus adalah karena itulah yang indah di dalam Tuhan. Hal ini merujuk pada ketataan anak terbatas pada "di dalam Tuhan"

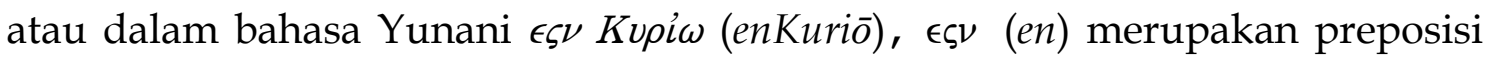
utama yang menunjukkan posisi seperti tempat, waktu dan keadaan, yang memiliki arti di dalam, oleh, dan, bersama, dengan, sedangkan Kupi $\omega$ (Kuriō) berasal dari akar kata Kúpıs (Kuriōs) merupakan kata benda yang berkasus datif (kata yang menduduki fungsi sebagai objek tidak langsung), maskulin, tunggal, merupakan gelar tertinggi dalam otoritas, pengontrol, pemilik, tuan, gelar ini diberikan kepada Allah, sang Mesias, jadi kata ini dapat diartikan Kristus sebagai Allah. Jadi ayat ini memilikiarti anak taat kepada orang tua dalam segala hal oleh tindakan yang berkenan atau diterima oleh Allah. Ketaatan anak kepada orang tua tidak bersifat mutlak, anak harus menaati Kristus lebih dari ketataannya kepada orang tua. Anak-anak menaati orang tua sepanjang ketaatan tersebut tidak melanggar kehendak Tuhan. Model ketaatan adalah ketaatan Kristus kepada Allah Bapa, ketaatan anak kepada orang tua adalah aturan moral yang berlaku dalam umat milik Kristus yang juga berarti menghidupkan Kristus dalam hubungan anak-orang tua, sehingga prinsip selanjutnya dalam ayat ini adalah ketaatan dalam segala hal, yang dikehendaki Tuhan.

Ayat 21 berbunyi: "hai bapa-bapa, janganlah sakiti hati anakmu supaya jangan tawar hatinya.Kata "sakiti hati" berasal dari bahasa Yunani é $\rho \epsilon \theta i \zeta \epsilon \tau \epsilon$ (erethizete) merupakan kata kerja, orang kedua, jamak, kini, aktif, imperatif, yang memiliki akar kata $\epsilon \varsigma \rho \epsilon$ Oi $\varsigma \omega$ (erethiso) yang berarti untuk merangsang atau membangkitkan kemarahan. Dalam bahasa Inggris provoke, yang berarti menggusarkan, menyakiti hati, mengganggu, membangkitkan, memancing. Hal ini merupakan perintah bagi orang tua atau dalam bahasa Yunani $\pi \alpha \tau \epsilon ́ \rho \epsilon \varsigma$ (pateres) yang memiliki arti ayah/orang tua, dimana anak telah menaati orang tua, maka 
seharusnya ayah tidaklah membangkitkan atau mengganggu anak dengan tujuan agar tidak menyebabkan tawar hati. Tawar hati terjadi akibat rusaknya hubungan antara orang tua dan anak. Kata ini hanya muncul dua kali dalam Perjanjian Baru, yakni dalam 2 Korintus 9:2 dan Kolose 3:21 yang artinya samasama menstimulasi, atau merangsang, hanya saja dalam Kolose 3:21 ini yang dimaksud adalah merangsang kemarahan. Ayah harus mencari cara positif agar tidak menyakiti hati anaknya sehingga anak menjadi tawar hati, salah satunya dengan membangun relasi melalui kepedulian dan pemberian kepercayaan kepada anak, tidak ada kecurigaan. Kecurigaan akan mengganggu bahkan merusak hubungan ayah dan anak. Anak pun harus menjaga hubungannya dengan ayah dengan cara menjaga kepercayaan yang telah diberikan oleh sang ayah, dengan begitu maka relasi atau hubungan antara ayah dan anak akan terjalin sehingga tidak ada tawar hati dalam diri anak. Prinsip keharmonisan yang penulis ambil adalah menjaga hubungan, yaitu takut akan Tuhan (ayat 18), kasih (ayat 19), ketaatan (ayat 20), komunikasi (bahasa verbal, non-verbal) (ayat 21), kepedulian (ayat 21), keteladanan (bertindak seperti takut akan Tuhan, kasih, ketaatan, komunikasi, kepedulian dll) (ayat 18-21).

Penelitian ini bertujuan untuk menganalisa isu-isu terkait dengan etika pergaulan siswa di sekolah, secara khusus dengan studi kasus di SD Kristen Kalam Kudus Yogyakarta dengan menyertakan kajian peran keluarga di dalam pembentukan karakter anak. Kemudian menganalisa keeratan hubungan antara keharmonisan sebuah keluarga dengan dan etika pergaulan siswa di Sekolah Dasar Kristen Kalam Kudus Yogyakarta.

\section{Metode}

Metode Penelitian yang digunakan dalam hal ini adalah penelitian kuantitatif deskriptif dengan menggunakan rumus pearson product moment dengan penghitungan skor pada skala likert, yang pada setiap butir soalnya telah teruji validitas dan reliabilitas. Pengambilan sampel menggunakan teknik cluster sampling, yaitu dengan menyebarkan kuisioner kepada siswa kelas $\mathrm{V}$ Sekolah Dasar Kristen Kalam Kudus Yogyakarta sebanyak 50 orang murid. Fokus penelitian yang digunakan adalah korelasi, yang mana peneliti melihat keeratan hubungan antara dua variabel yang diteliti. Jadi penelitian ini pada prinsipnya mencari keeratan hubungan antara keharmonisan keluarga menurut Kolose 3:18-21 $(\mathrm{X})$ terhadap etika pergaulan siswa $(\mathrm{Y})$, yang pada penelitian ini 
menggunakan siswa kelas V Sekolah Dasar Kristen Kalam Kudus Yogyakarta sebagai sample. Angket yang dikumpulkan dianalisa menggunakan SPSS.

Penulis mengajukan hipotesis penelitian $\mathrm{H}_{1}$, yakni: terdapat hubungan yang signifikan antara variabel Keharmonisan Keluarga berdasarkan Kolose 3:18-21 (X) terhadap Etika Pergaulan Anak (Y). Selain itu, penulis juga mengajukan beberapa hipotesa alternatif yaitu: pertama, terdapat hubungan yang signifikan antara kasih dalam keluarga terhadap kemampuan anak bertoleransi di sekolah. Kedua, terdapat hubungan yang signifikan antara kepedulian dalam keluarga terhadap sikap ramah di sekolah. Ketiga, terdapathubungan yang signifikan antara komunikasi yang baik dalam keluarga dan etika sopan santun di sekolah.

\section{Hasil dan Pembahasan}

\section{Hasil}

Berikut merupakan hasil dari perhitungan kuisioner dengan skala likert dan dihitung menggunakan rumus pearson product moment. Sebagai standar nilai untuk mengetahui kuatnya korelasi antar variabel, maka di bawah ini penulis menyajikan nilai interpretasi koefisien korelasi (Kasmadi dan Nia Siti Sunariah, 2016).

Tabel 1. Nilai Interpretasi Koefisien Korelasi

\begin{tabular}{cc} 
Interval Koefisien & Tingkat Hubungan \\
\hline $00.00-0.199$ & Sangat rendah/tidak ada hubungan \\
\hline $0.20-.0 .399$ & Rendah \\
\hline $0.40-0.599$ & Cukup \\
\hline $0.60-0.799$ & Kuat \\
\hline $0.80-1.00$ & Sangat Kuat \\
\hline
\end{tabular}

Tabel 2. Korelasi antara Keharmonisan Keluarga menurut Kolose 3:18-21 terhadap Etika Pergaulan Siswa

\begin{tabular}{llll}
\hline & & $\begin{array}{l}\text { Keharmonisan } \\
\text { Keluarga }\end{array}$ & $\begin{array}{l}\text { Etika Pergaulan } \\
\text { Siswa }\end{array}$ \\
\hline $\begin{array}{l}\text { Keharmonisan } \\
\text { Keluarga }\end{array}$ & $\begin{array}{l}\text { Pearson } \\
\text { Correlation }\end{array}$ & 1 &, $667^{* *}$ \\
\cline { 2 - 4 } & Sig. (2-tailed) &, 000 \\
\cline { 2 - 4 } & $\mathrm{N}$ & 50 & 50 \\
\hline Etika Pergaulan & Pearson &, $667^{* *}$ & 1 \\
\cline { 2 - 4 } & & &
\end{tabular}




\begin{tabular}{llll}
\hline Siswa & Correlation & \\
\cline { 2 - 3 } & Sig. (2-tailed) &, 000 & \\
\cline { 2 - 3 } & $\mathrm{N}$ & 50 & 50 \\
\hline
\end{tabular}

**Correlation is significant at the 0.01 level (2-tailed).

Sumber: Data Primer 2020

Berdasarkan analisa korelasi yang telah dilakukan dengan menggunakan SPSS versi 23, dengan menggunakan rumus pearson product moment dapat disimpulkan bahwa ada hubungan yang kuat antara Keharmonisan Keluarga menurut Kolose 3:18-21 terhadap Etika Pergaulan Siswa Sekolah Dasar Kristen Kalam Kudus Yogyakarta. Pernyataan tersebut dapat dilihat dari nilai interval korelasinya yakni 0,667, yang berdasarkan tabel acuan interpretasi koefisien korelasiadalah kuat.

Tabel 3. Analisa Korelasi antara Kasih dalam Keluarga dan Kemampuan Anak Memiliki Kemampuan Toleransi

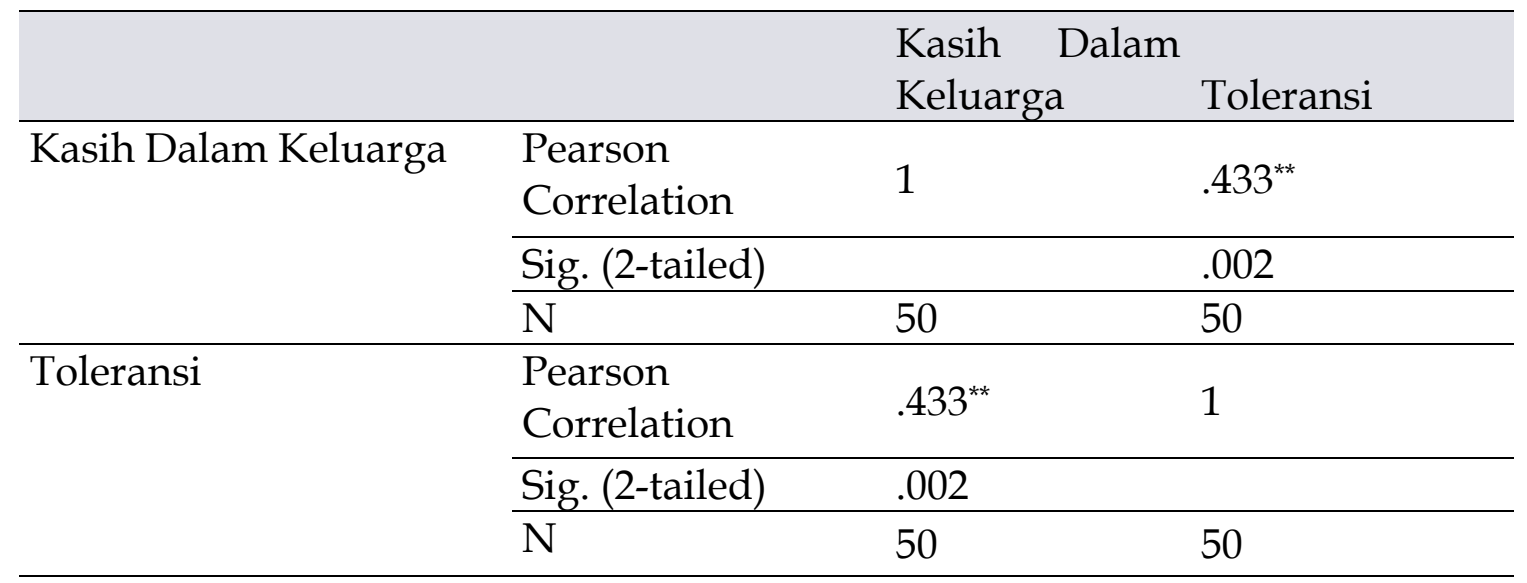

**. Correlation is significant at the 0.01 level (2-tailed).

Sumber: Data Primer 2020

Berdasarkan analisa korelasi yang telah dilakukan, tabel di atas menunjukan adanya hubungan antara kasih di dalam keluarga terhadap sikap toleransi siswa. Menurut acuan interpretasi koefisien korelasi, nilai yang ditunjukkan pada tabel di atas adalah 0,433 , artinya ada hubungan yang cukup kuat antara kasih dalam keluarga terhadap sikap toleransi.

Tabel 4. Analisa Korelasi antara Kepedulian Dalam Keluarga dengan Sikap Ramah

\begin{tabular}{llll}
\hline & & $\begin{array}{l}\text { Kepedulian } \\
\text { Dalam Keluarga }\end{array}$ & Ramah \\
\hline $\begin{array}{l}\text { Kepedulian } \\
\text { Dalam Keluarga }\end{array}$ & $\begin{array}{l}\text { Pearson } \\
\text { Correlation }\end{array}$ & 1 & $.605^{* *}$ \\
\cline { 2 - 4 } & & & \\
\end{tabular}




\begin{tabular}{llll}
\cline { 2 - 3 } Sig. (2-tailed) & .000 \\
\cline { 2 - 4 } $\mathrm{N}$ & 50 & 50 \\
\hline Ramah & Pearson & $.605^{* *}$ & 1 \\
Correlation & & \\
\cline { 2 - 4 } & Sig. (2-tailed) & .000 & 50 \\
\cline { 2 - 4 } & $\mathrm{N}$ & 50 & \\
\hline
\end{tabular}

**. Correlation is significant at the 0.01 level (2-tailed).

Sumber: Data Primer 2020

Berdasarkan tabel analisa korelasi di atas, dapat dilihat bahwa ada hubungan antara kepedulian dalam keluarga terhadap sikap ramah. Menurut acuan interpretasi koefisien korelasi, tabel di atas menunjukkan nilai 0.605, yang berarti ada hubungan yang kuat antara kepedulian dalam keluarga terhadap sikap ramah anak.

Tabel 5. Analisa Korelasi Antara Komunikasi Yang Baik Dalam Keluarga Terhadap Etika Sopan Santun

\begin{tabular}{|c|c|c|c|}
\hline & & Komunikasi & \\
\hline & & Dalam Keluarga & Sopan Santun \\
\hline Komunikasi & Pearson & 1 & $605^{* *}$ \\
\hline Dalam Keluarga & Correlation & 1 & .00 \\
\hline & Sig. (2-tailed) & & .000 \\
\hline & $\mathrm{N}$ & 50 & 50 \\
\hline Sopan Santun & Pearson & $101^{* *}$ & 1 \\
\hline & Correlation & & 1 \\
\hline & Sig. (2-tailed) & .004 & \\
\hline & $\mathrm{N}$ & 50 & 50 \\
\hline
\end{tabular}

${ }^{* *}$ Correlation is significant at the 0.01 level (2-tailed).

Sumber: Data Primer 2020

Berdasarkan tabel analisa korelasi di atas, dapat dilihat bahwa ada hubungan antara komunikasi yang baik terhadap sikap sopan santun. Nilai analisa korelasi di atas adalah 0.401, yang menurut nilai analisa korelasi di atas berarti memiliki hubungan yang cukup kuat antara komunikasi yang baik dalam keluarga terhadap sikap sopan santun siswa. 


\section{Pembahasan}

Penelitian yang telah dilakukan penulis menunjukkan bahwa penerapan prinsip-prinsip keharmonisan keluarga menurut Kolose 3:18-21 memiliki peran kuat di dalam pembentukan etika pergaulan siswa di sekolah. Sebaliknya, temuan juga menunjukkan apabila prinsip-prinsip keharmonian keluarga seperti yang ada di dalam Kolose 3:18-21 tidak diterapkan, maka terjadi kecenderungan adanya pelanggaran dalam etika pergaulan/pergaulan yang tidak sehat dikalangan siswa di sekolah. Fakta di atas menunjukkan pentingnya peran orang tua dalam pembentukan karakter anak, bahkan hal-hal kecil yang kecilpun membawa dampak yang besar. Temuan ini meneguhkan keyakinan bahwa keluarga dan orang tua adalah "sekolah" mula-mula bagi anak tentang nilai-nilai etis di dalam interaksi sosial di lingkungan yang lebih luas (Jatmiko, 2019). Oleh sebab itu sebagai orang tua Kristen perlu menyadari secara utuh perannya serta pengaruhnya terhadap kehidupan anak, sehingga dapat lebih serius dan berhati-hati dalam proses mendidik anak.

Kasih merupakan elemen wajib dalam formulasi Kolose 3:18-21 untuk membentuk nilai-nilai etis seorang anak. Nilai koefisien korelasi 0,433 menunjukkan bahwa kasih yang dirasakan anak di dalam keluarga membawa pengaruh yang kuat terhadap kemampuan toleransinya di sekolah. Pembelajaran dan pengalaman seorang anak dikasihi di rumah, terbukti berimplikasi pada pola interaksi anak-anak dengan teman-teman mereka di sekolah. Di dalam konteks keluarga, atmosfer kasih akan efektif di dalam halhal sederhana dan yang dilakukan secara terus menerus. Misalnya: Mama bangun pagi untuk menyiapkan sarapan, kebebasan untuk cerita kepada orang tua, adanya quality time seperti bermain dan belajar bersama orang tua. Temuan menunjukkan bahwa hal-hal sederhana tersebut ternyata memiliki pengaruh yang kuat terhadap sikap toleransi siswa terhadap teman disekolah. Siswa yang bertumbuh di dalam keluarga yang diwarnai kasih akan mampu menerima perbedaan, memiliki toleransi dan solidaritas yang lebih seta lebih menghargai teman - tidak suka mengejek teman (karena kelemahan, perbedaan status, latar belakang, dll.)

Prinsip kepedulian di dalam keluarga yang disebutkan di dalam teks juga terbukti menjadi kunci pentinguntuk menumbuhkan karakter yang sehat di dalam diri seorang anak. Nilai koefisien korelasi 0.605 menunjukkan pengaruh yang kuat antara kepedulian di dalam keluarga dengan bagaimana seorang anak berinteraksi dengan temannya di sekolah. Kepedulian orang tua 
bukan hanya berkait pada kebutuhan jasmaniah semata, tetapi juga pada aspek psikologis, sosial,emosi, dan spiritual seorang anak. Dipenuhinya setiap aspek kebutuhan anak akan menolongnya bertumbuh secara seimbang. Kepedulian dalam rumah akan berpengaruh kuat dengan sikap ramah siswa terhadap siswa lain di sekolah. Kesibukan orang tua, tuntutan pekerjaan, nilai-nilai materialisme menjadi ancaman besar bagi dipenuhinya tugas orang tua di dalam memperhatikan anak. Kurangnya waktu dan perhatian orang tua kepada anak, akan menanamkan nilai serupa di dalam diri anak terhadap teman-teman mereka di sekolah dan di lingkungan bermain.

Prinsip komunikasi yang sehat di dalam Kolose 3:18-21 juga merupakan kunci penting di dalam membentuk anak yang mampu menerapkan etika sopan santun di dalam pola interaksi mereka. Nilai analisa korelasi 0.401 menunjukkan bahwapola komunikasi memiliki hubungan yang cukup kuat dengan sikap sopan santun siswa. Di dalam keluarga, anak-anak akan melihat pola komunikasi orang tua mereka. Bagaimana ayah dan ibu berdiskusi, saling menyapa, mendengarkan, bertukar pendapat, menyatakan ketidaksetujuan, meminta maaf dan lain sebagainya. Hal tersebut terbukti membawa pengaruh yang kuat terhadap etika sopan santun siswa disekolah, seperti tidak duduk di atas meja, meminta ijin ketika meminjam barang teman, dan berbicara dengan bahasa verbal dan bahasa tubuh yang baik. Telah dijelaskan dibagian sebelumnya bahwa anak melakukan apa yang mereka lihat dan mereka dengar. Apabila yang dilihat dan yang didengar anak adalah hal yang tidak baik, maka itu pula yang akan dilakukannya terhadap oranglain. Orang tua tidak akan memberikan pendidikan yang efektif jika hanya mendidik lewat kata-kata tanpa keteladanan. Semua analisa korelasi di atas mengacu pada satu prinsip penting yaitu keteladanan orang tua, baik dalam hal kasih, kepedulian dan komunikasi. Sebab seorang anak adalah peniru teladan orang tua, meniru apa yang dilakukan orang tua daripada yang diucapkan/kata-kata. Keluarga menjadi tempat pertama-tama anak-anak mendapatkan nilai-nilai hidup termasuk nilai-nilai etis di dalam pergaulan. Di sinilah first-hand basis values ditanamkan di dalam diri anak (Hutcheon, 1999, pp. 129-134). Keluarga menjadi tempat di mana anak-anak mendapatkan fondasi nilai-nilai etis yang akan mereka gunakan di dalam interaksi mereka dengan sesama di lingkungan yang lebih luas. 


\section{Implikasi}

Apabila prinsip-prinsip keharmonisan keluarga dalam Kolose 3:18-21 (Takut akan Tuhan, kasih, ketaatan, komunikasi, kepedulian serta keteladanan) di lakukan secara konsisten oleh setiap keluarga, maka hal tersebut akan memiliki dampak besar bagi kehidupan keluarga terutama anak-anak bahkan generasi penerus bangsa. Dimana anak-anak akan memiliki karakter yang baik, etika yang baik, dapat meminimalisir kasus-kasus pelanggaran etika seperti pergaulan seperti bullying, tawuran, menyontek bahkan dalam jangka panjang akan meminimalisir kasus-kasus pelanggaran etika yang lebih besar seperti perselingkuhan, perceraian bahkan KKN. Dampak lain adalah meningkatnya kesadaran orang tua untuk lebih serius dalam mendidik anak, sebab keluarga adalah "sekolah" pertama bagi anak, dimana anak meniru semua hal yang dilakukan orang tua dalam sebuah keluarga. Apabila semua orang tua dalam keluarga serentak memiliki kesadaran untuk melakukan prinsip-prinsip keharmonisan keluarga maka akan membawa dampak jangka panjang yang lebih besar yaitu pembangunan moral/karakter bangsa dan pembangunan karakter Kristus.

\section{Rekomendasi untuk Penelitian Lanjutan}

Pertama, orang tua perlu menyadari pentingnya keseriusan dalam mendidik anak, tidak melepaskan tanggungjawab mendidik anak kepada siapapun. Memiliki komitmen untuk melakukan setiap prinsip-prinsip guna membangun keharmonisan dalam keluarga dengan begitu akan berdampak pada nilai-nilai karakter dalam diri anak yang akan terbawa di dalam lingkungan pergaulannya dengan orang lain (gereja, sekolah dan lingkungan masyarakat). Kedua, guru juga perlu memperhatikan setiap pengajaran yang diberikan kepada anak/siswa sebab pengajaran yang diberikan oleh guru menjadi acuan yang akan ditiru oleh siswa. Guru juga menyadari perannya bukan hanya sebagai penyampai materi namun juga dapat membangun hubungan, memiliki dedikasi yang tinggi dalam mengemban tugas yang berpengaruh pada nilainilai karakter anak. Ketiga, sekolah perlu menyadari peran keluarga dalam membentuk karakter dan mendukung hal tersebut dengan cara meningkatkan kemitraan sekolah rumah (mengadakan seminar parenting, mendirikan forum komite untuk sekolah dan orang tua membahas masalah karakter anak, responsif terhadap keluhan orang tua tentang permasalahan karakter anak). Untuk menekan angka bullying, program buddy 
adalah pogram yang baik untuk dipertahankan, dapat juga di dukung dengan adanya komunitas kelas, penerapan program service excellent/morning meeting (sharing guna memecahkan masalah secara bersama-sama, kegiatan outdoor, games, seminar tentang bahaya bullying dll).

\section{Kesimpulan}

Penelitian yang dilakukan penulis membawa simpulan yang harus diperhatikan bagi pendidik, pemerhati, maupun setiap orang tua. Faktor bawaan, lingkungan, pergaulan tidak bisa selalu dijadikan sebagai "kambing hitam" berkaitan dengan karakter anak. Keluarga memiliki peran penting dalam membentuk karakter, dan mengadopsi nilai-nilai sopan santun di dalam berinteraksi dengan keluarga. Keharmonisan keluarga adalah parameter kunci dalam etika pergaulan anak di dalam tumbuh kembang mereka di lingkungan sosial. Keluarga Kristen harus mengembangkan budaya harmonis yang bercirikan takut akan Tuhan, kasih, ketaatan, keteladanan, komunikasi dan kepedulian. Secara khusus, bagai gereja pengajaran tentang prinsip ini perlu lebih ditekankan di dalam konseling pranikah, pelayanan keluarga, khotbah tematik, retreat keluarga dan berbagai pelayanan keluarga yang lain.

\section{Rujukan}

Anouw, Y. (2016). Kepemimpinan Rumah Tangga Suku Meree di Kaimana. Jakarta: BPK Gunung Mulia.

Barus, A. (2018). Tafsiran Alkitab Kontekstual Al-oukumenis: Surat Kolose. Jakarta: BPK Gunung Mulia.

Boyer, J. L. (1987). A Classification of Imperatives: A Tatistical Study. Grace Theological Journal, 8(1), 35-54.

Brookes, A. (2003). A critique of neo-Hahnian outdoor education theory. Part one: Challenges to the concept of "character building." Journal of Adventure Education \& Outdoor Learning, 3(1), 49-62. https://doi.org/10.1080/14729670385200241

Eduard, Lohse. (2018). Colossians and Philemon (Philadelphia: Fortress, 1971) dalam buku Armand Barus, Tafsiran Alkitab Kontekstual Al-Oukumenis: Surat Kolose. Jakarta: BPK Gunung Mulia.

Ewert, A. W., \& Sibthorp, J. (2014). Outdoor adventure education: Foundations, theory, and research. Human Kinetics. 
Handsbook Code Of Conduct Tahun Pelajaran 2019/2020. (2019). Yogyakarta: Sekolah Kriten Kalam Kudus Yogyakarta.

Hutcheon, P. D. (1999). Building Character and Culture. Praeger.

Jahroh, W. S., \& Sutarna, N. (2016). Pendidikan Karakter Sebagai Upaya Mengatasi Degradasi Moral. Prosiding Seminar Nasional Inovasi Pendidikan, 395-402.

Jatmiko, B. (2019). Teologi Keluarga: Kajian Terhadap Kejadian 1-3. Sanctum Domine, 6(2), 83-102.

Kasmadi dan Nia Siti Sunariah. (2016). Panduan Modern Penelitian Kuantitatif. Bandung: Alfabeta.

New English Translation, Alkitab Android. (n.d.). diakses pada 22 Mei 2020, pukul 20.15 WIB.

Packer, J. I., Tenney, M. C., \& White Jr., W. (2014). Ensiklopedi Fakta AlkitabBible Almanac-2. Malang: Gandum Mas.

Prouty, D., Panicucci, J., \& Collinson, R. (2007). Adventure education: Theory and applications. Human kinetics.

Purnamasari, D. (2017). Pendidikan Karakter Berbasis Al-Quran. Islamic Counseling: Jurnal Bimbingan Konseling Islam, 1(1), 1. https://doi.org/10.29240/jbk.v1i1.233

Robertson, A. T. (1934). A Grammar of the Greek New Testament in the Light of Historical Research. Nashville: Broadman.

Shelton, J.-A. (1998). As the Romans Did: A Sourcebook in Roman Social History (2nd ed.). New York: Oxford University Press.

Syarbini, A. (2014). Model Pendidikan Karakter Dalam Keluarga. Jakarta: Gramedia. William Barclay. (2005). Pemahaman Alkitab Setiap Hari: Surat Filipi, Kolose, 1 Dan 2 Tesalonika. Jakarta: BPK Gunung Mulia.

Wulandari, Y. (2012). The nation's character building through value education. Jurnal Pendidikan Karakter, 2(1), 55-66. 